https://doi.org/10.24101/logos.2020.03

Gauta 20200129

AIVARAS STEPUKONIS

Lietuvos kultūros tyrimų institutas, Lietuva

Lithuanian Culture Research Institute, Lithuania

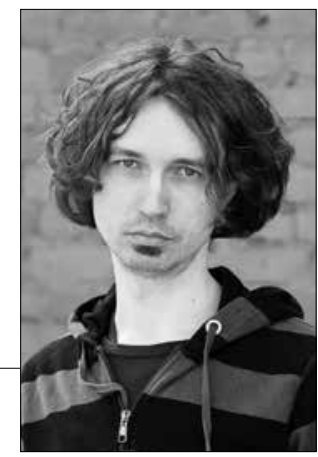

\title{
EPISTEMINÉ STEBĖJIMO FORMŲ PASKIRTIS IMMANUELIO KANTO GRYNOJO PROTO KRITIKOJE
}

\author{
The Epistemic Function of the Forms of Intuition \\ in Immanuel Kant's Critique of Pure Reason
}

\begin{abstract}
SUMMARY
The article constitutes a detailed exposition of the epistemic role Immanuel Kant assigns to the forms of intuition in his magnum opus Critique of Pure Reason. Special attention is directed to the notions of sensibility, intuition, experience, and knowledge. At the center of the investigations into the forms of intuition is Kant's epistemological turn from realism to transcendentalism: the subject comes to experience the object by constituting it, not by correspond to it. The article closes with a few critical observations regarding the concept of 'thing in itself,' the limitation of external reality to the sensible and material realms, and the analytic obscurity of 'given' and 'represented,' two central concepts which are often used in the passive voice without specifying their agents.
\end{abstract}

\section{SANTRAUKA}

Straipsnyje nagrinėjama episteminė stebėjimo formu paskirtis Immanuelio Kanto Grynojo proto kritikoje. Itin daug dèmesio skiriama juslumo, stebėjimo, patyrimo ir pažinimo sampratoms. Tiriant stebèjimo formas, išryškinamas epistemologinis Kanto posūkis nuo realizmo prie transcendentalizmo: subjektas patiria objektą sąmonëje ji sudarydamas, o ne atitikdamas; stebẻdamas objektą subjektas jam suteikia suprantamą formą veikliai perkeldamas į objektą iš anksto nulemtas prigimtines savo pažintinių gebų sąlygas (apibūdinamas terminu transcendentalus), o ne imliai atspindèdamas paties objekto savybes. Straipsnis baigiamas kritinėmis pastabomis apie probleminę sąvoką pats daiktas (savaime), abejotiną išorinès tikrovės ribojimą jusline ir medžiagine sritimis bei analitinį terminų duota ir vaizduojama neaiškumą, dažnai vartojant neveikiamuosius dalyvius ir nenurodant veikejjų. 


\section{INTUITION}

In his analysis of the logical employment of the understanding, Kant states that intuitions are the only sort of representations that function "in immediate relation to an object" (Kant 1961: 105). This is said in contrast to the operations of concepts, the proper media of the understanding, which have no immediate relation to objects but rather must deal with some other representation, either a concept or an intuition. As a result, intuition is always antecedent to any and every act of understanding (ibid.: 84). Its [intuition's] immediate relation to objects has to be further specified in that it is a relation to objects in the "mode in which [humans] are affected by objects" (ibid.: 93).

Intuitions are only possible insofar as objects are given to the human being (ibid.: 65). In other words, the presentation of objects to man is imperative, if their representation is to occur in man. Actual objects must be given to man before actual intuitions may result therefrom. Three essential features of intuition have thus been enumerated: a) its immediate relation to objects: $b$ ) its determination according to the mode in which objects affect man; c) its prerequisite that objects are actually given. The participation of the above qualifications in what intuition is, according to Kant, is what makes the latter exclusively sensible versus its intellectual counterpart.

Next, Kant distinguishes two components constitutive of all intuitions. In examining these two components, he avails himself of the traditional philo- sophical concepts of matter and form. Kant proceeds in the following manner: every intuition contains a mere sensation such as color, sound, or heat, etc. This is the component of the intuition that constitutes its matter. Sensation, in turn, is derived from the way in which objects impress themselves on man. Yet, as such sensation is devoid of intelligibility and "does not [...] yield knowledge of any object" (ibid.: 73). Heed must be directed, as a result, to the other component involved in the intuition, to wit, its form. Kant observes that the sensation of an intuition is always determined into an order of relationships; an order which is the form of the intuition gathering the "manifold" of that sensation under an intelligible unity (ibid.: 66). Further, the form of intuition thus defined is by no means to be confused with the matter of intuition, i.e., sensation. The form itself cannot be sensation, nor can it be derived from sensation because of their qualitative difference; a difference between the intelligible and sensible, which is "transcendental" and "concerns their origin and content" (ibid.: 84). Nor may the form be explained by means of sensation, since the latter by its nature defies such a capacity to explain, itself being rendered comprehensible only inasmuch as it stands under the order of relationships supplied to it by the form of the intuition. In Kant's view, therefore, the form holds a kind of priority over the matter in that it alone is able to provide the matter with an intelligible structure which is a necessary condition for the 
emergence of an intuition. This priority he calls the a priori character of the form of intuition.

Intuitions are called empirical when they contain sensation which, in turn, presupposes the actual presence of an object. Such empirical intuitions Kant sets apart from what he titles pure intuitions. The latter are characterized by a total dissociation from sensation. This distinction Kant is able to accomplish only by paying the cost of terminological ambiguity. The reason is that, "Pure intuition [...] contains only the form under which something is intuited [...]" (ibid.: 92). As a result, what Kant had previously called merely the formal component of intuition, which of itself cannot constitute the entirety of intuition unless complemented by sensation, now is given the name of intuition, even if with the specification "pure."

It has already been noted that the form of intuition cannot be explicated by means of sensation, as the latter itself is in need of an intelligible structuring which can only be supplied by the very form of intuition. Now, sensation is the outcome of the way in which man is affected by an object. A question may be raised, therefore, as to whether the form of intuition could not be accounted for by the nature of the object of that sensation. Such an explanation, in fact, would perhaps demonstrate that the form of intuition grounded in the objective nature of a thing external to that intuition must itself be objective. This, however, seems to beg the question, since the most immediate manner in which the object is presented to man is the very sensation caused by it. In other words, it is by having sensations of an object that one becomes aware of the existence of that object; in a similar fashion, it is through those sensations that a nature comes to be ascribed to the object sensed; the sensations that, as has been indicated, by themselves, according to Kant, lack intelligibility. Therefore, if nothing external or immediately internal (i.e. sensation) to man can account for the source of the form of intuition, the search for such a source must move in the direction of the mediate operation of human intelligence. After an assiduous study using different arguments, Kant is led to conclude that the form of intuition stems from the subjective constitution of the human mind. This discovery ${ }^{1}$ implies a radically different view of objects which will be fleshed out in more detail in the following section whose preoccupation is with the faculty of sensibility.

\section{THE FACULTY OF SENSIBILITY}

Man is in possession of a multiple complex of intuitions which as a whole constitutes a proper epistemic apparatus known as the faculty of sensibility. Kant construes intuitions as "forms" of sensibility (Kant 1961: 66), but it would be more precise, in my opinion, to call them [intuitive] organs because the term "form" carries the connotation of a thorough disengagement from sensation and a kind of universal subjective application, whereas an "organ" retains the 
sense both of individuality and actual sensitivity, the two aspects inherent in every [empirical] intuition.

Kant's own definition of the faculty of sensibility is as follows: it is the "capacity for receiving representations through the mode in which we are affected by objects" (ibid.: 65). This statement is worth a careful analysis. By "capacity" Kant means that which is able and not the "capacity per se," since the latter's literal sense is an abstraction with as yet no sense of any actuality which seems to be essential to the faculty of sensibility if it is to be understood as a complex of actual sensible intuitions. "Representations" here simply refer to the contents of sensible intuitions. The second part of the statement, however, is of particular interest, since if taken literally it would stand in stark contradiction to one of Kant's major theses, namely, the objects in themselves are not known. To speak of the mode in which we are affected by objects is equivalent to saying something about the mode as it is determined by the objects themselves, to wit, as they affect man by virtue of what they are. That is, the statement in its present form asserts that the 'mode through which we are affected by objects' pertains to objects themselves and not to us, and therefore to say something about that mode is to say something about the character in which objects act toward us as that character is determined by the objects themselves. Now, this somewhat ironical conclusion is obviously inconsistent with what Kant otherwise would claim to be the case. As a result, the correct version of the statement would read as follows: sensibility is the 'capacity for receiving representations by way of our [subjective] mode through which we are affected by objects.'

The discipline which studies the nature and operations of the faculty of sensibility is termed by Kant aesthetic. It is the science of the rules of sensibility in general (ibid.: 93). Aesthetic is transcendental when one prescinds from any interdependence on sensation. The methodology of transcendental aesthetic is threefold: a) isolating from sensibility all that is thought through the concepts of understanding; b) separating from sensibility all that belongs to sensation; c) examining the forms of sensibility which are prior to any sense experience (ibid.: 67). Since on account of the limitations set by the parameters of my work it is impossible to try to see through Kant's implementation of this procedure, a brief acquaintance with its results should therefore suffice.

The two forms governing the intelligible aspect of the faculty of sensibility, as opposed to sensation, are those of space and time. These forms are called "pure" because in no way are they affected or determined by sensation. On the contrary, they themselves determine sensation in the single way in which the latter may become intelligible data. If the forms of space and time are removed, no intelligible experience may result. I have mentioned that for Kant the provider of the form of every intuition is the subjective constitution of the human mind. Every individual manifestation of intuition contains in its act the form(s) of space and/or time. With respect to the faculty of sensibility as contrasted to in- 
dividual intuition, the forms of space and time are understood in a universal sense, thus signifying the fact that they are found in every intuition without exception. Space and time, as a consequence, must be recognized as the necessary conditions for the very possibility of experience whose source looms in the subjective constitution of the human mind.

The impossibility of the knowledge of objects in themselves, though already intimated in brief, now becomes fully evident. The subjective forms of space and time do not belong to what objects are in themselves, but to the manner in which man represents them [objects] to himself. Even so, each and every object of which man is ever conscious is and, in fact, must be in space and/or in time. It follows, then, that all sensible representations of objects are possible only if formed according to the subjective conditions of space and time, which are due to the human mind and not to the objects themselves. The result is that all we know by means of the faculty of sensibil- ity is appearances of objects as opposed to those objects in themselves.

What objects may be in themselves [...] remains completely unknown to us. We know nothing but our mode of perceiving objects (ibid.: 82).

It must be noted that the talk about the mode of sensibility and its epistemic relation to the objects given is a question of essence and not degree. That is to say, objects are not intuited as they are in themselves not because of the lack of clarity in intuition, nor because of its [intuition's] confused and disordered operations, but because of the very nature of sensibility, its fundamental structuring that functions in such a way as to represent the object according to its own character and not that of the object itself. Consequently:

Even if we could bring our intuition to the highest degree of clearness, we should not thereby come any nearer to the constitution of objects in themselves. We should still know only our mode of intuition, that is, sensibility (ibid.: 83).

\section{EXPERIENCE AND KNOWLEDGE}

Starting with the simplest faculty operative in the sensible segment of the whole process of knowledge formation, i.e., sensation, and then expanding to intuition and sensibility, experience is at last reached. It stands in almost no need of additional explanation, since in most cases Kant's usage of the term is equivalent to that of sensibility. In this context it should also be observed that the term "perception" has almost always the meaning of an "intuition." Nevertheless, a slight distinction, though somewhat hypothetical, may be noticed. When Kant discourses about sensibility, what he is usually addressing is the faculty as conceived of through its functions and operations. It is, in other words, the mechanical and the structural side of sensibility. Whereas by experience, it would seem, Kant intends to mean the actual content of sensibility insofar as it is a content that is actual. Experience as an actual content of sensibility also presup- 
poses a consciousness of the actual intuitions not as separate sensible occurrences but as a single totality achieved in the unity of those intuitions.

Although one may say that experience does constitute a part of the process of knowledge formation, just by itself it is not yet knowledge, if the latter is taken in its specialized sense delineated in the opening paragraphs of this article. An epistemic cooperation between experience and concepts, which are the product of the understanding, is necessary if knowledge is to be obtained. Nor do concepts in and of themselves constitute knowledge because "to think an object and to know an object [are not] the same thing" (ibid.: 161). Without experience, concepts remain void forms of thought; without concepts (including the concepts of space and time), experience remains imprisoned beneath the level of intelligibility. Thus, Kant's famous passage: "Thoughts without content are empty, intuitions without concepts are blind" (ibid.: 93).

\section{GENERAL CRITICAL OBSERVATIONS}

Kant critically re-evaluates the relationship between consciousness and objective reality. For him it is not a relation of correspondence, understood in the realist sense, but rather a relation of constitution. Intuition, as a consequence, is meant to be an integral element contributing to an understanding of the reciprocal relation of constitution between things and consciousness.

The pursuit described above, I surmise, was the original insight of Kant. I believe, nevertheless, that he failed to attain his goal. The reason is that he was not entirely able to free himself from certain concepts which his philosophy from the start was supposed to confute. An example of such a concept is 'objects in themselves.' Its use reveals the fact that Kant could not help but view the constitutive relation between consciousness and things as a conditional relation of distortion, in this way tacitly affirming against his own will - that consciousness with respect to its nature is accidental to the nature of objects, just as the latter with respect to their nature are accidental to the nature of consciousness. Profound as my appreciation of Kant's innovative intention is, I remain unconvinced of his concrete philosophical solution.

Kant's treatment of the categories of space and time in the exposition of the "Transcendental Aesthetic" is an object of contention, too. The explication of the concept of space appears especially inadequate. Kant seems to work under the prejudice that all external reality must be sensory and material. This is not selfevident at all. If the only realms of existence were those of the material and the psychical, then any entity posited not to exist in any of these realms must be concluded not to exist at all. Such an entailment, however, cannot be obtained from the strict logic of the proposition, and should be subjected to serious philosophical misgivings.

Finally, careful as Kant is in the application of his theoretical vocabulary, 
still, certain of his terms seem to be used precisely because of the semantic ambiguity contained in their signification. Even now, after a more or less assiduous study of the Critique, I feel quite unconfident as to the exact meaning of the concepts 'given' and 'representation.' One's understanding of these notions will palpably determine one's interpretation of what is meant by objects in themselves or the actuality of intuition.

Another enigma concerning these concepts stems from the almost exclusive usage of these terms in the passive voice, viz., something is given and something is represented. This presupposes an agency the problem of which is nowhere in

\section{References}

Hume David. 1900. An Enquiry Concerning Human Understanding. Chicago: The Open Court Publishing Co.

Kant Immanual. 1902. Prolegomena to Any Future Metaphysics. Translated by P. Carus. Chicago: The Open Court Publishing Company.

\section{Endnotes}

1 Provoked as much as inspired by David Hume's skeptical conception of causation (Hume 1900) and its ostensibly fatal consequences to the apo- the Critique addressed. That is to say, an object is given to man by means of sensibility and is thus said to be represented in man. The meaning of the latter statement cannot be equivalent to an object giving itself, nor to an object taken by the subject, since if this was the sense these expressions might easily have been implemented. This ambiguity seems rather alarming. In the final resort, it is for every philosopher in private to decide how crucial it is to the validity of Kant's arguments. My own judgment is that unless these terms are critically defined and accounted, their unintelligibility does stand in a position to undermine great portions of his philosophy.

Kant Immanuel. 1781. Kritik der reinen Vernunft. Riga: verlegts Johann Friedrich Hartknoch.

Kant Immanuel. 1961. Critique of Pure Reason. Translated by N. K. Smith. London: Machmillan.

Kant Immanuel. 1996. Grynojo proto kritika. Iš vokiečių k. vertẻ R. Plečkaitis. Vilnius: Mintis.

deictic certainty of scientific knowledge that "interrupted [Kant's] dogmatic slumber" (Kant 1902: 7). 